\title{
Justifiable Renewable Energy Usage from an Economic Angle
}

Ádám CSUVÁR

PhD Student

Kaposvár University, Faculty of Economics

Department of Regional Studies and Statistics

40 Guba S. St, H-7400 Kaposvár

E-mail: csuvar.adam@ke.hu

\begin{abstract}
Worldwide, there is a huge demand for the application of renewable energy technologies mainly due to the current environmental problems that mostly originated from our fossil-based energy system. This study is aiming at presenting areas which require a bigger share of renewables from the global energy mix but only for economic reasons. We highlight that these alternatives can bear with advantageous economic effects compared to the non-renewable ones. We take into account renewables-based business opportunities, and then we discuss the positive effects of renewables on economic development. Finally, we look at the issuant security of energy supply and talk about beneficial labor market impacts caused by renewable energies.
\end{abstract}

Keywords: renewable energy, energy economics, energy policy

JEL Classifications: O13, Q42, Q43

\section{Introduction}

The Earth's population is showing an intensively growing figure. According to certain forecasts, by 2100, more than 11 billion people might be living on our planet (United Nations, 2015). If we consider only the physical needs of these people, it is purely a serious challenge to provide an appropriate quantity and quality of food, drinking water, accommodation, etc. to them. And still we have not even considered further needs which necessarily come with our "compulsory" consumption. As, parallel to this, a huge economic growth is present in the Far- East, several areas of Africa, and South America - the rate of this economic growth is higher than in the case of developed countries, and in a few decades it would dramatically change the current economic roles (PwC, 2015). Reviewing the abovementioned facts, considering it as a whole, the result 
is not really surprising: a huge growth of energy demand can be forecast, which cannot be satisfied using current practices and without facing fatal problems.

Fossil fuels provide the basis for the energy system of the Earth. 85\% of our current energy production is made up of non-renewable energy sources (BP, 2016), which carry several environmental, economic, and political risks. If we rely on the fossil fuels the same way, we will face more and worse environmental catastrophes, geopolitical conflicts, or even wars, which would also lead to the realization of a pessimistic proof forecasting not 10 billion but a total of only 2-3 billion people by the end of the century. To avoid the fulfilment of the ominous outlook, it is essential to restructure our current energy structure. We will replace non-renewable energy sources with renewable ones.

But we also have to see that the dangers of using fossil fuels do not only come in the form of environmental damages. These risks and problems are not harmful to the natural environment alone. Several contradictions appear both economically and strategically, which could be reduced with the help of renewable sources.

In the following, we intend to review areas which justify the use of alternative technologies for some economic reasons. The novelty of this study appears in that it simultaneously covers different areas of the economy, areas that are strongly affected by renewables. The disadvantage arises from the same approximation; the broad spectrum makes it impossible to deeply explore each area. There have been many articles that approach these issues separately, but we do not know of any papers that would match them altogether. Amri (2017), Al-mulali et al. (2013), Ohler and Fetters (2014), Rafindadi and Ozturk (2017), and Bhattacharya et al. (2017) soundly dealt with the connection between renewables and economic growth. Frankfurt_SchoolUNEP_Centre/BNEF (2015), Smartinvest (2015), IRENA (2016a), and Christensen and Hain (2017) analysed the renewable energy investment opportunities. The employment impacts caused by renewables were examined by Bezdek (2009), Lehra et al. (2016), UCSUSA (2013), Zhao and Luo (2017), Garrett-Peltier (2017), and Sari and Akkaya (2016). Silva et al. (2016), Tóth (2014), Mathiesen et al. (2011), and Kumar (2016) investigated the role of renewable energies in the security of energy supply.

After this introduction, the body of the essay, "Results and discussion" follows. In its first subsection, we discuss the "Economic problems of fossil fuel dominancy"; then, we move on to have a look at some "Business opportunities with renewables". In the third subsection, we explicate the "Stimulation of economic development" by renewables. Finally, we summarize the benefits of energy security and the issuant employment caused by renewable energies in the "Enhancing the security of energy supply" and "Expansion of employment" subsections. At the end of the paper, we summarize our ideas in the last section titled "Summary and conclusions".

We would also like to add that the usage of renewable energy can have partly disadvantageous effects on economy (e.g. boosting prices, difficult schedule 
keeping, system integration costs, and anomalies); however, the purpose of this paper is not to account for these effects; so, we will deal with them only tangentially.

\section{Results and Discussion}

\section{Economic Problems of Fossil Fuel Dominancy}

The usage of fossil fuels significantly took part in the evolution of global warming and resulted in several political conflicts. Nevertheless, we could discover further problems while paying a bit more attention to the wholesale energy market. The world market price of petroleum - and the closely related natural gas - is highly dependent on the supply and demand principles and on speculations, due to which the price is unpredictable even in the short run. This situation can become more complicated thanks to the political actions ("oil weapon") and the business strategies of giant companies. Figure 1 clearly demonstrates the irregular, unforeseeable fluctuation of market prices. Although the graph shows only the oil price, the pricing of fossil fuels and their replacement nature in energy production determines a connection between them, which also means that the three products' (oil, coal, and gas) prices affect one another and follow a similar trend (Csermely, 2016).

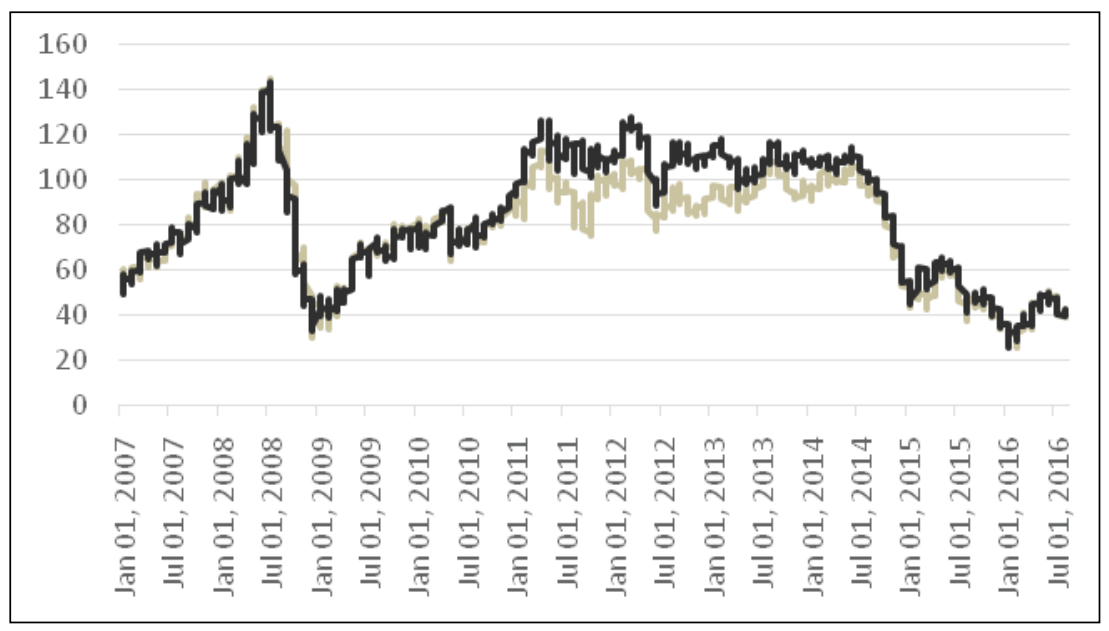

Source: IEA, 2016

Figure 1. Changes in the price per barrel of WTI (grey) and Brent (black) crude oil (USD) 
The situation is problematic because, besides oil being a key raw material in several industries, it is also an essential standard in world economy, a relevant commodity in the exchange market, which is why it influences most of economic life in a direct or indirect way. Oil crises $(1973,1979,2014)$ pointed out every time that this dependency should be decreased. Initially, a few affected regions could create a spill-over effect through complicated interregional relations, which could influence all parts of the world, determining this way the inflation, investment volume, disposable income, etc. Export-dependent Venezuela is a perfect example nowadays; the inflation was 121\% in 2015 (World Bank, 2016) due to the depressed oil prices.

The radical price volatility and crises of fossil fuels always lead us to the conclusion: their role played in the world market should be decreased. This step should start with the diversification of global energy structure, as currently $80 \%$ of energy is powered by fossil fuels. Renewable energy would take the leading role in the diversification because it can be found everywhere on Earth (even if not in the same potential), and its application would not result in (significant) negative externalities (apart from a few exceptions such as hydroelectric power plant, certain geothermic wells, biomass, etc.). After the initial installation, the "fuel" for the production is already available for free (except biomass); so, the variable cost of the production is very low.

\section{Business Opportunities with Renewables}

Not only the economic results are stressed by the unforeseeable volatility but its impact determines the investment behaviour as well. At first glance, the fact might seem surprising that despite the fall of oil (fossil) prices renewable energy investments expanded in a wider range than non-renewables during last year (Nyquist, 2015). Considering the renewables as replacement products, economic logic would state that a certain price stress, pressure of return would lead to the usage of more innovative, more costly technology; definitely not in the case of low prices. But real life shows various different examples.

Year 2015 might bring a watershed in terms of energetic structure alteration considering that this was the first year when the volume of renewable energy investments of developing countries exceeded the same volume as that of developed countries; moreover, it was the first time when the ratio of renewable electricity investment (53.6\%) was higher than the investment ratio of fossil-based power plants (Frankfurt_School-UNEP_Centre/BNEF, 2015).

This is, of course, not the result of an error or a coincidence; there is logic behind the facts if we take a closer look. On the one hand, due to the (supra) national expectations (e.g. EU2020, China) and subsidies, the renewable energy primarily electricity - projects provide a rapid return and a low risk investment 
(REKK, 2014). Their expansion and pricing can be more easily estimated and show a more solid picture than that of the fossil fuels (Richter, 2013). As Almulali et al. (2013: 209) write, "the constant fluctuation in the price of fossil fuels encouraged many countries in the world to increase their investment on renewable energy".

This predictable and (often) regulated market environment initiates special investment forms open for "anyone". For instance, one of the investment forms can be a green chip, which covers the shares of an environmentally conscious company; or a green bond, where the money collected after issuing the bonds is surely invested in "sustainable projects". The latter one was issued exceeding 48 billion dollars in 2015, which was also a record compared to last years' figures (REN21, 2016). We shall also mention the yieldcos, which stands for the subsidiaries of corporations dealing with renewable energy offering attractive dividends (Smartinvest, 2015).

The yields of domestic power plants are also not negligible - they show a better return rate; so, this area is getting more attractive to the public with savings just like the community plants, which means that committed people with savings are willing to pre-finance a "renewable project" - besides an appropriate business structure -, which is finally rented by the operator in the long run (Smartinvest, 2015). Furthermore, it can be stated that there is a growing willingness shown by investment banks, retirement funds, and insurance companies in the direction of renewable energy investments (Frankfurt_School-UNEP_Centre/BNEF, 2015).

On the other hand, due to technological development and economies of scale in production, the installation cost of the alternative energy is constantly decreasing. The unit cost of the electricity produced by solar cells decreased by $58 \%$ between 2010 and 2015 (IRENA, 2016), and significant cost decrease can be observed in the case of other technologies too. This way, in a few areas having outstanding facilities, considering pure market conditions, the renewable energy projects can compete with the technologies based on non-renewable resources. With this tendency, the lack of considerable financial capital might not be a limiting factor in the investments, especially if the forecast is coming true, according to which by 2025 the investment cost of solar technology can decrease by $59 \%$ (IRENA, 2016). Obviously, a considerable price decrease is very likely in terms of other methods as well, which will progressively diminish the disadvantage of alternative energy.

In short, we can say the mentioned examples share that the basic driving force of the investments is not reaching economic stability or protecting the environment but purely validation of self-interest and desire for profit, which can be fulfilled even more often by the renewable-based constructions. The investment volume regardless of its motivation - is having an effect on the economic performance, the state of environment, and it can also push them into the direction of development. 


\section{Stimulation of Economic Development}

The excessive expansion of renewable capacity does impact the world or a national economy performance. Based on the calculations of International Renewable Energy Agency (IRENA) (2016a), GDP will increase by 0.6-1.1\% due to the doubling of renewable energy capacity by 2030. Al-mulali et al.'s (2013) work states that in most cases GDP and renewables determine and affect each other's volume. Chien \& Hu (2007) demonstrate that the growing use of renewable energies develops macroeconomic performances.

As in conventional cases the investment itself increases the value of Gross Domestic Products, it increases the output of the energy sector and the employment. By reducing the fossil import, it stimulates the foreign trade balance to be active. Although investments can operate as an engine of economic growth, they can also limit the two typical driving forces of the improvement (Póyry/Camecon, 2014).

The renewable energy is still in an active innovation phase, and so, considering the regular costs, they are not competitive compared to fossil fuels, but they are more preferable thanks to the subsidies by the state (Fodor, 2013). The charges of the subsidy are involved in the retail prices; so, that is eventually paid by the public and/or the industrial sector. Higher energy prices worsen the competitiveness of the industrial sector and its export, so, the foreign trade balance as well. High prices limit public consumption, which could serve as another pillar for economic growth besides export. We will add that high prices can be also considered as a driving force of the energy efficiency investments. On the other hand, investments require import technology, which can also worsen the foreign trade balance. Summarizing the effects, we would finally get to a net positive effect in terms of GDP (Domac, Richards, and Risovic, 2005).

\section{Enhancing the Security of Energy Supply}

Several papers (e.g. Europen_Union, 2006; REKK, 2011) handle stable energy supply of a certain territory as an economic dimension; so, in the upcoming sections, it is reviewed what roles can be played by the alternative production methods. An energy system is said to be secure if the required energy is available in the proper amount and quality besides acceptable risks (Gács et al., 2006). The need for secure supply is getting more important due to modernization and urbanization, plus the service sector is getting more dominant.

Apart from a few countries (such as Iceland or Norway), fossil-based energy systems are in use worldwide, but most of the countries do not own a proper amount of resources that could meet their own needs, and so they cover their demand by means of international trading. 
Figure 2 presents the tendency of energy import dependency with regard to Hungary and the EU-28. Ignoring the impact of the global crises on energy consumption, we can discover that the energy dependency of both territories is continuously growing, although concerning Hungary the ratio of import is way above the EU average. Hungary covers $61.7 \%$ of the total consumption by importing energy resources.

Hungary's natural resources are not able to meet self-sufficiency requirements, but its dependency can be mitigated if the country can boost the domestic energy ratio in the energy mix (internal security of supply). The nuclear-coal-green scenario of National Energy Strategy 2030 (NFM, 2012) is aiming to achieve this goal.

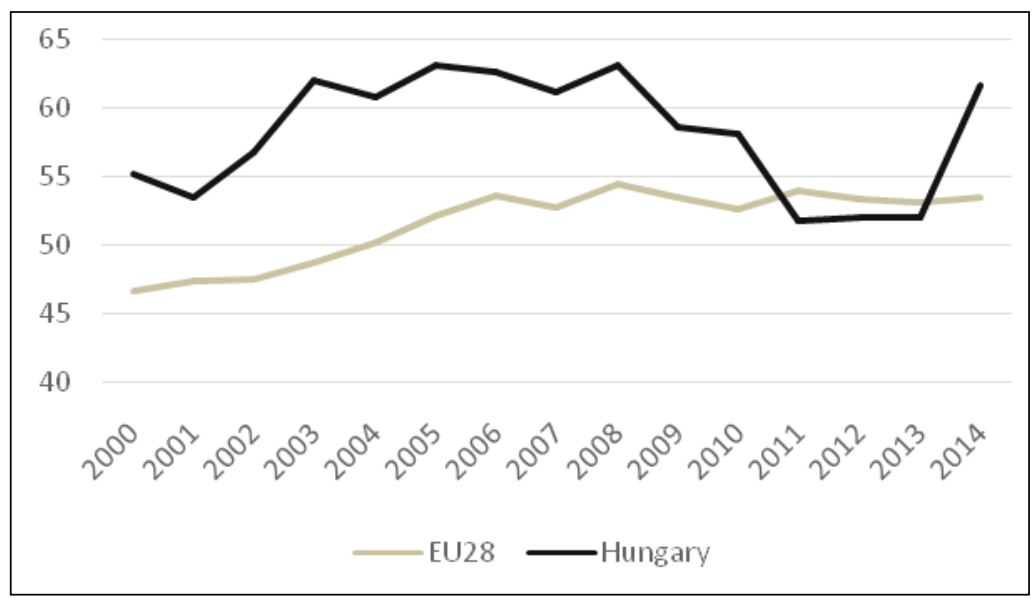

Source: Eurostat, 2016

Figure 2. Energy dependency rate of Hungary and the EU-28 (\%)

In our opinion, as the technology and the fuel of the nuclear plant is also coming from (Russian) import, this will not improve self-sufficiency largely, sustainably - even if the uranium is storable in a relatively big amount, in contrast with the exploitation of the domestic coal and lignite reserve, which is controversial to the environmental sustainability due to its negative environmental effects. As Hungary has an outstanding potential regarding a few renewable energy sources (geothermic, solar, biomass), it would be reasonable to use renewables in order to enhance the country's security of supply. Renewables are able to reduce import dependency and diversify the portfolio of energy sources as well as decrease the overall risk of energy supply (Mathiesen et al., 2011; Kumar, 2016).

Based on the results of an international research studying 12 EU countries (mostly Central Eastern European countries, including Hungary), it can be stated that in case 
of achieving the 2030 energy efficiency and renewable energy goals, ${ }^{1}$ the natural gas demand of the countries could be reduced by $20 \%$ (Tóth et al., 2014).

\section{Expansion of Employment}

The spread of renewables is not negligible in terms of available job opportunities either because it covers the area of equipment production, maintenance, design, research and development, consultancy, and marketing. As for IRENA (2016b) calculations in 2015, the number of employees working directly or indirectly in the renewable industry exceeded 3 million, out of which the photovoltaic energy section had the biggest share of employment. It will be highlighted that the mentioned socio-economic impact can be interpreted as rather a positive externality than a direct action.

The production can reach a large segment of the population. The least special but the most labour-dependent biomass can provide jobs to unskilled workers, replacing social expenses. Qualified people can be employed in areas requiring unique skills and conditions such as the production, design, and development of products in the solar or wind energy section. Locally accumulated know-how can create an exportable industrial segment, which can even become a determinant part of the national economy (such as in Spain, Denmark, or Germany). Additionally, production aiming at foreign market has a multiplicative effect on employment, rather than as if it aimed at domestic markets alone (Bezdek, 2009; Lehra et al., 2016).

Another positive effect is that the production of renewable energy equipment is more labour-intensive than fossil technologies; it requires twice as much worker per one invested dollar (UCSUSA, 2013). According to Garrett-Peltier (2017: 446): "the $\mathrm{EE}^{2}$ and $\mathrm{RE}^{3}$ industries generate nearly three times as many jobs as $\mathrm{FF}^{4}$ industries, for the same level of spending”. The second largest job creator in the sector is the biomass production (IRENA, 2016b), which is suitable for enhancing the economic and social prospects of rural areas (e.g. Brazil), as it is fixed to a certain territory.

\section{Summary and Conclusions}

The present study aims at summarizing the most important positive economic impacts connected to the application and spreading of renewables. We first reviewed the weaknesses of the energy system exposed to fossil fuels and the world

1 https://ec.europa.eu/clima/policies/strategies/2030_en.

2 Energy efficiency.

3 Renewable energy.

$4 \quad$ Fossil fuel. 
economy that they have overtaken. It has been concluded that the diversification of the energy mix with renewables would be able to diminish the dependency of non-renewables, which would be reasonable due to reoccurring crises, political conflicts, and price stability problems.

Subsequently, it has been shown that renewable-based construction is gaining more relevance than a business, investment opportunity; due to this, it shows a more predictable picture than non-renewables. Furthermore, the profitability of renewables is continuously improving parallel to their decreasing cost.

Then, their advantages have been demonstrated on the macroeconomic level because they can initiate economic growth by means of investments. It can also have a positive effect on the output of energy and industrial sector, foreign trade balances, or even the consumption of the population, which are all contributing to economic growth.

Expanding their capacity can increase a certain region's secure energy supply with the diversification of energy structure and can diminish the demand for non-renewables only available by import.

Finally, the impact on employment was analysed. It is not negligible that a large segment of the population can work in various areas from agricultural raw material production to research and development. While in the former case mostly rural areas and unskilled workers can benefit, in the latter case, cities with developed infrastructure and skilled workers can gain profit.

\section{References}

Al-mulali, U.; Fereidouni, H. G.; Lee, J. Y.; Sab, C. N. (2013). Examining the bidirectional long run relationship between renewable energy consumption and GDP growth. Renewable and Sustainable Energy Reviews 22: 209-222.

Amri, F. (2017). The relationship amongst energy consumption (renewable and nonrenewable) and GDP in Algeria. Renewable and Sustainable Energy Reviews 76: 62-71.

Bezdek, R. (2009). Green Collar Jobs in the U.S. and Colorado. Colorado: American Solar Energy Society.

Bhattacharya, M.; Churchill, S. A.; Paramati, S. R. (2017). The dynamic impact of renewable energy and institutions on economic output and $\mathrm{CO} 2$ emissions across regions. Renewable Energy 111: 156-167.

Blazejczak, J. (2014). Economic effects of renewable energy expansion: A modelbased analysis for Germany. Renewable and Sustainable Energy Reviews. 1079. BP. (2016). BP Energy Outlook 2016 edition. Outlook to 235. BP plc.

Chien, T.; Hu, J. L. (2007). Renewable energy and macroeconomic efficiency of OECD and non-OECD economies. Energy Policy 35: 3606-3615. 
Christensen, J. L.; Hain, D. S. (2017). Knowing where to go: The knowledge foundation for investments in renewable energy. Energy Research \& Social Science 25: 124-133.

Csermely, Á. (23 March 2016). Gázárak szabadesésben. Guruló Hordó. http:// gurulohordo.blog.hu/2016/03/23/gazarak_szabadesesben.

Domac, J.; Richards, K.; Risovic, S. (2005). Socio-economic drivers in implementing bioenergy projects. Biomass and Bioenergy 28: 97-106.

European_Commision. (April 2013). Member States' energy dependence: an indicator-based assessment. European Economy. Brussels: European Commission.

Europen_Union. (2006). Green paper: a European strategy for sustainable, competitive and secure energy. Brussels: European Union.

Fodor, B. (2013). Kihívások és lehetőségek a hazai megújulóenergia-szektorban. Vezetéstudomány 51.

Frankfurt_School-UNEP_Centre/BNEF. (2015). Global trends in renewable energy investment. Frankfurt.

Gács, I. et al. (8 April 2006). Magyarország primerenergia-hordozó struktúrájának elemzése, alakításának stratégiai céljai. Az új magyar energiapolitika tézisei a 2005-2030 közötti idôszakra - 9. fejezet. Budapest: Gazdasági és Közlekedési Minisztérium.

Garrett-Peltier, H. (2017). Green versus brown: comparing the employment impacts of energy efficiency, renewable energy, and fossil fuels using an inputoutput model. Economic Modelling 61: 439-447.

IEA. (2011). Energy Policies of IEA Countries - Hungary. France: International Energy Agency.

IRENA. (June 2016). The power to change: solar and wind cost reduction potential to 2025. United Arabic Emirates: IRENA.

(2016a). Renewable energy benefits: measuring the economics. United Arab Emirates.

(2016b). Renewable energy and jobs - annual review 2016. United Arab Emirates.

Kumar, S. (2016). Assessment of renewables for energy security and carbon mitigation in Southeast Asia: the case of Indonesia and Thailand. Applied Energy 163: 63-70.

Lehra, U.; Mönniga, A.; Missaouib, R.; Marroukib, S.; Salem, G. B. (2016). Employment from renewable energy and energy efficiency in Tunisia - new insights, new results. Energy Procedia 93: 223-228.

Mathiesen, B. V.; Lund, H.; Karlsson, K. (2011). 100\% renewable energy systems, climate mitigation and economic growth. Applied Energy 88(2): 488-501.

NFM. (2012). Nemzeti Energiastratégia 2030. Budapest: Nemzeti Fejlesztési Minisztérium. 
Nyquist, S. (June 2015). Lower oil prices but more renewables: What's going on? McKinsey \& Company. Available at: http://www.mckinsey.com/industries/oiland-gas/our-insights/lower-oil-prices-but-more-renewables-whats-going-on.

Ohler, A.; Fetters, I. (2014). The causal relationship between renewable electricity generation and GDP growth: A study of energy sources. Energy Economics 43: 125-139.

PŐYRY/CAMECON. (March 2014). The values of wind energy to Ireland. UK: Pöyry Management Consulting (UK) Ltd.

PwC. (February 2015). The world in 2050. PwC.

Rafindadi, A. A.; Ozturk, I. (2017). Impacts of renewable energy consumption on the German economic growth: evidence from combined cointegration test. Renewable and Sustainable Energy Reviews 75: 1130-1141.

REKK. (2011). Security of energy supply in Central and South-East Europe. Budapest: Aula Kiadó.

REKK. (2014). A megújuló alapú villamosenergia-termelés támogatási rendszereinek problémái és az uniós reform elképzelések. Jelentés az energiapiacokról 18.

REN21. (2016). Renewables 2016 - Global Status Report. Paris.

Richter, M. (2013). Business model innovation for sustainable energy: German utilities and renewable energy. Elsevier: Energy Policy 62: 1231.

Sari, A.; Akkaya, M. (2016). Contribution of renewable energy potential to sustainable employment. Procedia - Social and Behavioral Sciences 229: 316-325.

Silva, R. C.; Neto, I. de M.; Seifert, S. S. (2016). Electricity supply security and the future role of renewable energy sources in Brazil. Renewable and Sustainable Energy Reviews 59: 328-341.

Smartinvest. (2015). Befektetés az energetikába. Budapest.

Tóth, B. (October 2014). Towards 2030 - how can renewables and energy efficiency improve gas security in selected Member States? Dialogue on a RES policy framework for 2030.

UCSUSA. (May 2013). How renewable electricity standards deliver economic benefits. Renewables: Energy You Can Count On. Union of Concerned Scientist.

United Nations, D. o. (2015). World population prospects: the 2015 revision. New York: United Nations.

Zhao, X.; Luo, D. (2017). Driving force of rising renewable energy in China: environment, regulation and employment. Renewable and Sustainable Energy Reviews 68: 48-56. 